co-workers is emphasized throughout these sections of the book. An outstanding contribution comes in the final four chapters of Drewry's book, which review glacilacustrine, glaci-estuarine and glaci-marine processes and sedimentation. This is the first comprehensive compilation of such material in a text on glacial geology and is long overdue, since many present-day glacier systems terminate in water, as did vast sections of the last great ice sheets in the northern hemisphere.

The book is well written and well illustrated, and provides an admirable review of primary physical processes operating in the glacial environment. It is an excellent foundation for scholars already familiar with glacial geology and geomorphology. The book's weakness is that it fails to grasp a major opportunity to apply the understanding of such processes to the interpretation of ancient sediments and landforms. After all, glacial landforms represent the former ice-bed interface where many of the processes discussed in the book operated. However, David Drewry has pointed the way ahead for future bridge builders and is to be congratulated on a fine effort. (Chalmers $M$. Clapperton, Department of Geography, University of Aberdeen.)

\title{
KAYAKS AND UMIAKS
}

SKINBOATS OF GREENLAND. Petersen, H. C. 1986. Roskilde, the Viking Museum. 215p, illustrated, hard cover. ISBN 87-85180. Dkr400.00

This magnificent book is the first in a series produced in collaboration between the Viking Ship Museum in Roskilde, the Institute of Maritime Archaeology at the National Museum of Denmark, and (for this volume) the Museum of Greenland. The author discusses the construction and use of the kayak and umiak (now defunct) in Greenland. Besides using written sources and studying old specimens in museums, Petersen draws most strongly on his experience as a native Greenlander. His father and his mother's father, noted hunters and kayakers, feature in an extensive gallery of informants consulted over many years of travelling around the country. The author himself learned to build kayaks in order to appreciate fully the problems and techniques involved.

The main contribution of the book lies in the meticulous documentation of construction techniques and materials. The first half, dealing with the kayak, observes that construction proceeds from the load-bearing sheer boards, as opposed to the keel of a wooden boat, and leads systematically through the shaping of the sheer boards, cross beams, rib and keel, the covering with skin and the manufacture of accessories and fittings such as paddles, floats, throwing boards and harpoon heads. The second half gives a comparable discussion of the umiak, a larger boat used for family transport and rowed largely by women; the account places more emphasis on the social background to its use. The author discusses properties of different types of wood and skin, and processes for drying them. The wealth of detail and thoroughness will give great satisfaction to any craftsman, kayaker or ethnographer. This very detail makes the reader keenly aware of the sophistication and ingenuity deployed in adapting a very limited range of raw materials for precise tasks. The constant call on the builder's and hunter's judgement is illustrated most fundamentally in the subjective units of measurements, whether of size or of muscle capacity, by which the kayak is constructed. An isanneq (armspan) or an eqinneq (the circle formed by touching fingertips and thumb when gripping a paddle) are precisely tailored to the individual user, just as the kayak's width is related to his need to use his legs to control balance: the kayak becomes almost an extension of the body itself.

Historical background is presented for the most part only in its direct bearing on design and performance. There is no sociological analysis, but there are vividly evocative sketches of the social life involved in umiak travel. Petersen mentions rowing games to 
lessen fatigue, sexual teasing games, and the pleasure of the greenery and flowers in the summer reindeer hunting grounds experienced by families who had moved inland from the stormy spring coast, as well as the gatherings of many such families at the end of summmer before the return to the coast. Whether illustrating the constantly innovative fine tuning of equipment, or the social atmosphere in which activities were carried out, Petersen's anecdotes are to the point. The book is well produced and clearly printed, with over 200 diagrams and photographs in black and white. There is a list of place names in new and old orthography as well as Danish. The extensive Greenlandic-DanishEnglish glossaries at the back are divided into separate lists of kayak and umiak terms; these are useful, but the arrangement makes for repetition (not always with an identical gloss) and also excludes other useful words. The English of the text is excellent: occasional slips of the pen do not detract from the very pleasing effect of the book. It is good, too, to know that the editors hope to publish a version in Greenlandic. (Piers Vitebsky, Scott Polar Research Institute, Lensfield Road, Cambridge CB2 1ER.)

\section{SECURITY AND RESOURCES IN THE ARCTIC}

NORTHERN WATERS: SECURITY AND RESOURCE ISSUES. Archer, C. and Scrivener, P. 1986. London, Croom Helm. 240 p, I map, hard cover. ISBN 0-7099-0570-X. £25.00.

This book originated in the concern of the Scottish branch of the Royal Institute of International Affairs with strategic and resource issues in the North Atlantic sector of the Arctic and Subarctic. There are fifteen contributors from the US, Canada, Norway, Denmark and the UK. Focus is on the sea area between $60^{\circ}$ to $80^{\circ} \mathrm{N}$, and $90^{\circ} \mathrm{W}$ to $40^{\circ} \mathrm{E}$. These northern waters are important for three main reasons. First, they cover the northern limit of regular sea lanes between North America and Europe. Second, they have rich fish and petroleum resources which are significant on a global scale. Third, they have a strategic importance in that they lie between the two super powers; this aspect is the central concern of the book, and it is fascinating to read about the evolution of strategic ideas as technology advances. Whereas a few years ago NATO's defensive plans were to stop a possible Soviet break-out into the global ocean, today the Soviet Union can threaten the US from submarines which remain in the Barents Sea or even under the Arctic sea ice cover. The NATO response is to consider forward anti-submarine measures in the Arctic, tactics which obviously look less than defensive when seen through Soviet eyes.

The book has two main parts. The first seven chapters consider themes within the area as a whole. There are chapters on the implications of the Law of the Sea Convention for the area (which could help prevent creeping national claims of offshore seas), on natural resources, transport, strategy, new military technology and control of conflict. The latter chapter notes the lack of an overall political treaty for the Arctic, unlike the Antarctic, in spite of the presence of an indigenous pressure group, the Inuit Circumpolar Conference, and stresses the danger of not having an over-arching control organization. The second part of the book deals with resource and strategic perspectives of individual nations, and makes for most interesting reading. There are up-to-date reviews of resources in Arctic Canada (beyond the confines of northern waters), the USA, Greenland, Svalbard and the western Soviet Arctic, including shallow offshore areas. In addition different national perspectives on strategic issues are covered. The wrangle between the Soviet Union and Norway over offshore claims in the Barents Sea is a case in point. Norway argues for a median line between Svalbard on the one hand and Franz Josef Land and Novaya Zemlya on the other, pushing the claim as far east as possible. 